\title{
Paleoclimatic inference of the mid-Holocene record of monk seal (Monachus monachus) in the Cantabrian Coast
}

\author{
A.B. Marín ${ }^{\text {a,*}}$, M.R. González-Morales ${ }^{\text {b }}$, J. Estévez ${ }^{\mathrm{c}}$ \\ ${ }^{a}$ Leverhulme Centre for Human Evolutionary Studies, University of Cambridge, Fitzwilliam Street, Cambridge CB2 1QH, United Kingdom \\ ${ }^{\mathrm{b}}$ Instituto Internacional de Investigaciones Prehistóricas de Cantabria, Universidad de Cantabria, 39005 Santander, Spain \\ c Laboratorio de Arqueozoología, Universidad Autónoma de Barcelona, Bellatera, Barcelona, Spain
}

\section{A R T I C L E I N F O}

\section{Article history:}

Received 26 August 2010

Received in revised form 31 October 2010

Accepted 2 November 2010

Available online 3 December 2010

\section{Keywords:}

Mid-Holocene

Climate change

Monk seal

Cantabrian Coast

\begin{abstract}
A B S T R A C T
The mid-Holocene has been widely used to test the performance of the numerical models that are commonly employed to estimate the future evolution of world climate. This period, as the pollen record shows, was characterized by higher temperatures than present in northern and Central Europe, while cooler conditions occurred in the south of the continent. This pattern is challenging numeric algorithms that widely fail to replicate the paleoclimate data of southern Europe. Here we report the discovery of a fragmented bone of a temperate water phocid (Monachus monachus) dated to $5540 \pm 40 \mathrm{BP}$ that was hunted and consumed on the Cantabrian Coast during that period. This find implies a hitherto unnoted phase of warm conditions associated with strengthened advention of subtropical waters to the region. As a consequence, the possibility that the oceanographic regime from that time in the Bay of Biscay was similar to the current one is reinforced, a fact that could modify our view of mid-Holocene climate in the Iberian Peninsula and have important implications in climate change studies.
\end{abstract}

(c) 2010 The Geologists' Association. Published by Elsevier Ltd. All rights reserved.

\section{Introduction}

Paleoclimatic reconstructions are essential in our understanding of past human evolution and the predictions of future ecological developments. Physical and biological indicators, such as ice cores, speleothems, pollen, foraminifera and invertebrate and vertebrate faunas, have all been used in the past to build temperature curves (Dansgaard et al., 1993; Genty et al., 2003; Grootes et al., 1993; Guiot et al., 1996; Ruddiman, 1992) leading to an intense debate on the effects of climate change on human evolution (Behrensmeyer, 2006; Foley, 1994; Ruff, 2005; Trauth et al., 2007). In addition, they have been commonly applied to test the performance of climate numerical models and to identify the role of natural versus anthropogenic influence on climate (Brovkin et al., 1999; Claussen et al., 2002; Crucifix et al., 2002; Ganopolski and Rahmstorf, 2001; Jones et al., 1998; Weber, 2001). Some periods provide an outstanding opportunity for doing so. This is the case with the mid-Holocene climatic optimum, which occurred at around 6000 years BP, involving substantial changes in mean global temperature within a trend of steady warming without the presence of large ice sheets (Harrison et al., 1998; Steig, 1999).

\footnotetext{
* Corresponding author. Tel.: +44 07767 784982; fax: +44 01223764710.

E-mail addresses: abm38@cam.ac.uk (A.B. Marín), moralesm@unican.es (M.R. González-Morales), jordi.estevez@uab.es (J. Estévez).
}

As a climate proxy of that period, here we report the identification of Monachus monachus (monk seal) remains in the Bay of Biscay, a currently endangered and almost extinct phocid associated with warm subtropical waters that has been dated approximately to the mid-Holocene. A fragmented bone, identified as an ulna of this species and showing clear signs of human butchery, was recovered from La Fragua Cave, a small hunting camp on the present Cantabrian shore in northern Spain. This is the first time such a specimen has been retrieved in this region, which is widely known for its complete and abundant archaeological record during the Upper Palaeolithic and Mesolithic.

Apart from the zooarchaelogical relevance of the find, it also has an interesting climate significance. Thus, the thermal reconstruction commonly used for southwest Europe in the mid-Holocene, mainly based on the pollen record (Cheddadi et al., 1997; Davis et al., 2003), suggests that temperatures were lower than at present. However, the climate models that are currently available tend to encounter problems in achieving a good fit to those evidences (Bonfils et al., 2004; Brewer et al., 2006).

The fact that a temperate water phocid was found in the Cantabrian Coast during that period enables the possibility that the regime of sea currents was similar to the present one, including the predominant advection of warm waters from the subtropical Atlantic towards northern latitudes. This mechanism could have tempered the Holocene climate in southwest Europe as it does nowadays (Visbeck, 2002). If this was the case, climate models 
ought to take this into account, avoiding an unjustified bias towards cooler temperatures in that part of the continent, and thus, improving their general performance.

\section{Materials and methods}

La Fragua Cave is located at $125 \mathrm{~m}$ above sea level on the southeastern slope of Mount Buciero, in Santoña (eastern Cantabrian Spain) (see Figs. 1 and 2). The cave is relatively small - roughly $10 \mathrm{~m}$ long by $3 \mathrm{~m}$ wide at most - but is well sheltered and favorably oriented against winter conditions. Archaeological excavations carried out at the site between 1990 and 1996 revealed the existence of continuous human occupation from the late upper Magdalenian to the Neolithic (González Morales, 2000), making it one of the few Late Glacial sites on the Bay of Biscay coast to have survived the steady rise in sea level (González Morales et al., 1992).
From the subsistence point of view, this site has been described as a secondary camp for the exploitation of resources in its immediate surroundings (Marín and González-Morales, 2007), within a territorial system that would have included the whole Asón valley, with large habitation sites like El Mirón (Marín, 2008 , 2009 ) located in the interior area. Thus, the taxonomic composition of the recovered faunal assemblage is typical of a specialized hunting strategy focused on temperate fauna, mostly red deer and ibex although some wild boar and roe deer remains are also present. This taxa representation is coherent with the general pattern of the Cantabrian Coast during the Holocene and follows the progressive displacement of Arctic fauna observed during the Late Pleistocene (Straus, 1992). The seasonality of the site indicates that the cave was mainly occupied during later summer and autumn, when food were stored in considerable quantities in anticipation of the coming winter season (Marín, 2004). Further-

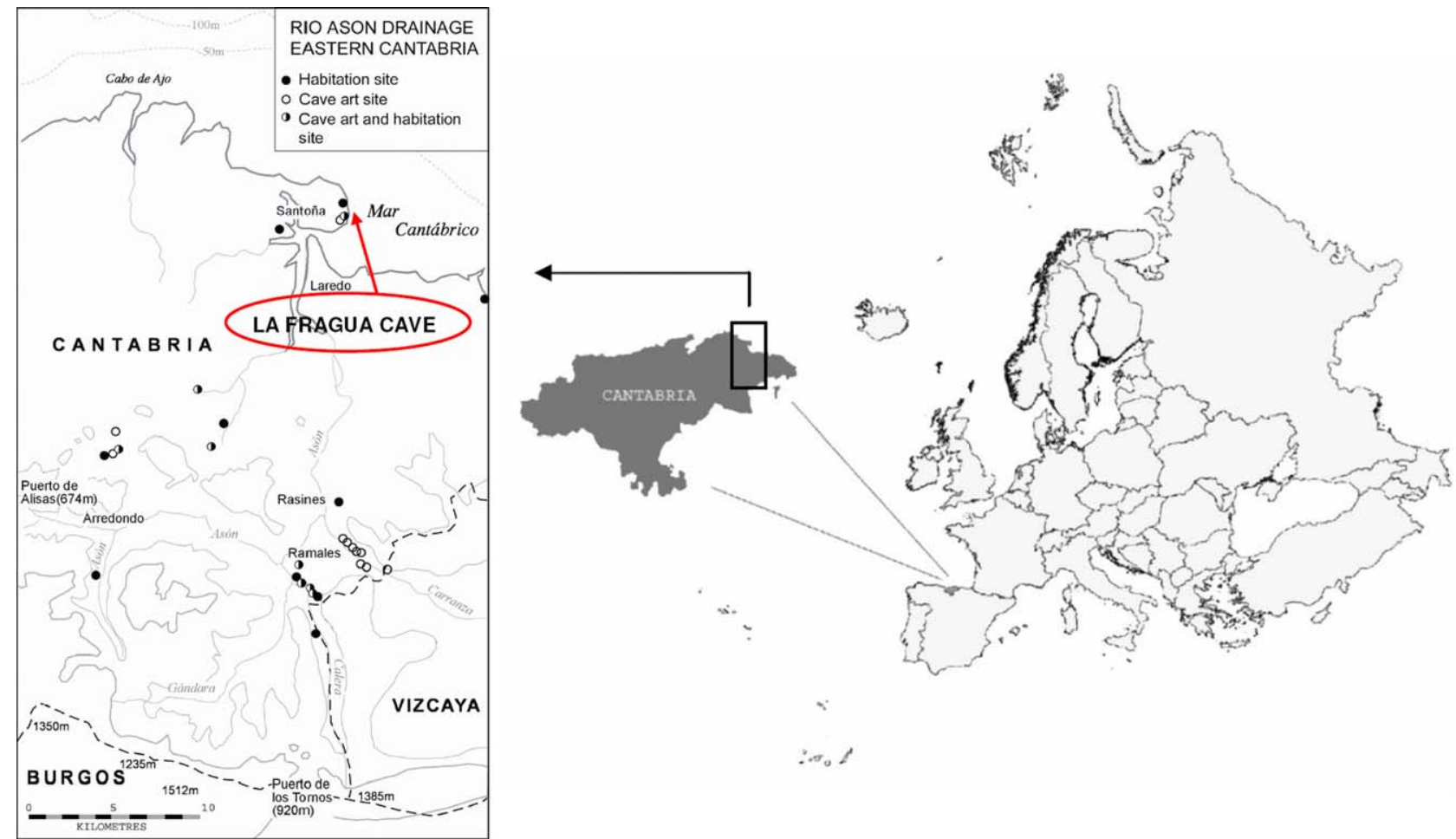

Fig. 1. Location of La Fragua Cave in the river Asón drainage basin in eastern Cantabria Province in Spain.
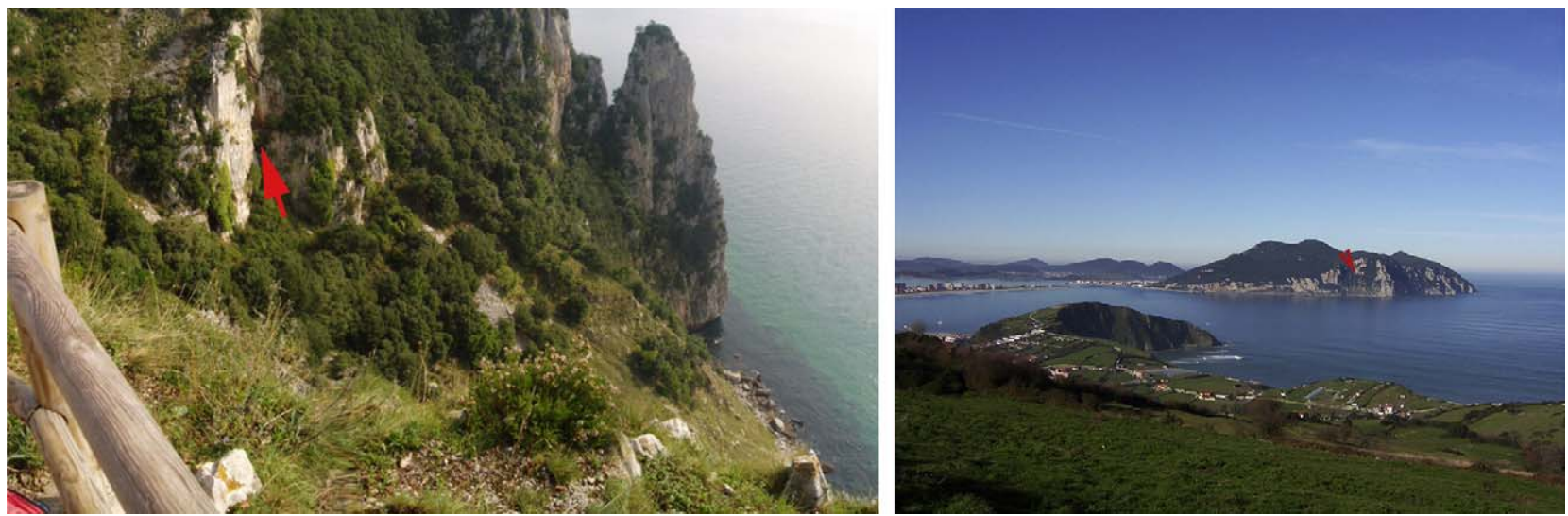

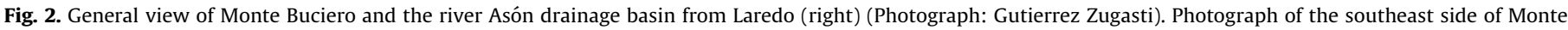
Buciero showing La Fragua Cave (the red arrow shows the present location of the cave) (left). 

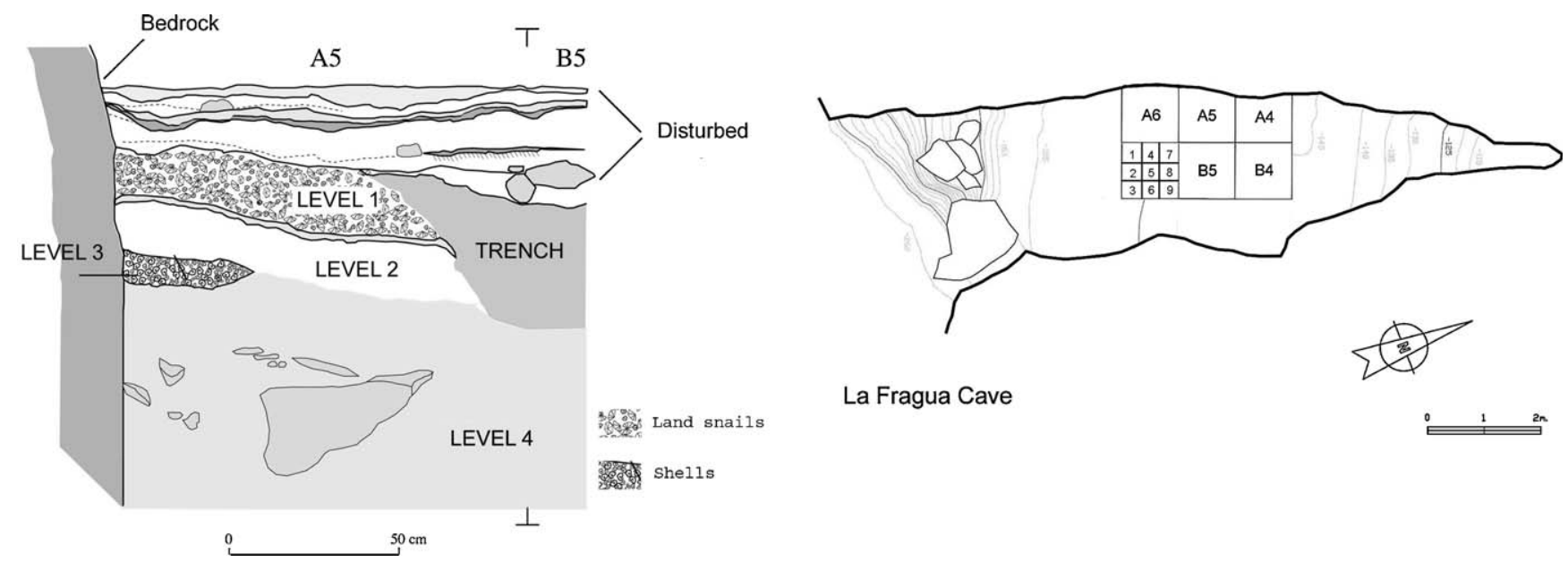

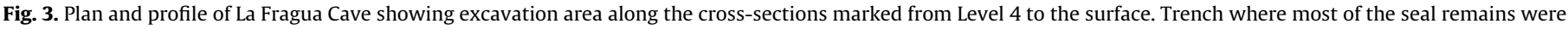
recovered. Level 3 was a horizon formed by land snails consumed by humans and Level 1 was a marine shell midden.

more, the exploitation of marine resources is documented by the large numbers of shells disposed of during the Mesolithic period (Gutierrez Zugasti, 2006).

Three of the four bone fragments that we report on here were found in a trench that was dated to Holocene in age and cuts through uppermost Pleistocene strata and the other one was recovered from the surface (Fig. 3). The fragments are from an ulna belonging to an adult individual, possibly male, of the Order Pinnipedia and Family Phocidae (Fig. 4). Despite being broken into four pieces, the careful work undertaken to refit the pieces during the archaeozoological study succeeded in reconstructing it almost completely, apart from the medial zone of the caudal edge of the diaphysis. The olecranon and articular zone were found on the land surface. Remains of this species have not been reported before from the Spanish shore of the Bay of Biscay.

The total weight of the bone is $62 \mathrm{~g}$, at an overall length $16.8 \mathrm{~cm}$. The bone is fused in the olecranon region, although in the caudal zone the spongy tissue is partially visible and the fused part has been lost. The state of preservation is good, but some vermiculations can be seen on its surface, with slight evidence of manganese oxide staining. Among other visible taphonomic alterations, the olecranon displays several incisions and scrape marks of anthropogenic origin, located in the medial zone, and oblique to the caudal edge. These are consistent with butchery tasks, such a dissecting the flexor digitorum profundus muscle of the anterior limb (see Figs. 4 and 5). This is, therefore, an individual that was prepared for human consumption and presumably caught in the immediate vicinity of the site that must have offered conditions well-suited for this species (González, 1999; Gucu et al., 2004: 418). In fact, Monte Buciero, contains numerous underwater caves that could have been an ideal breeding area for seals (see Fig. 2). The presence of these cut marks and the absence of ornamental features ruled out the possibility of long range transport of the carcass.

\section{Results}

From the start, bone morphology rules out the possibility that the specimen belong to the seal population that currently inhabits the North Atlantic Ocean (Sommer and Benecke, 2003) such as ringed seal (Phoca hispida), harp seal (Phoca groenlandica), bearded seal (Erignathus barbatus), grey seal (Halichoerus grypus) and harbour seal (Phoca vitulina). Of these, to date the only remains identified at Quaternary sites in northern Spain belong to $P$. vitulina, at Altamira (Altuna and Straus, 1976) and Tito Bustillo (Altuna, 1976), and to H. grypus, at La Riera (Altuna, 1986) and Las
Caldas (Corchón et al., 2008). Some Palaeolithic artistic depictions at Peña Candamo Cave (Asturias) may also be interpreted as phocids (Serangeli i Dalmau, 2001).

We then consulted the full comparative collections at the Museum National d'Histoire Naturelle in Paris, the Muséum Océanographique de Monaco, the Sociedad de Ciencias Aranzadi (San Sebastian, Spain) and the Natural History Museum in London, which include specimens of Phoca hispida (ringed seal), Phoca sibirica (Baikal seal), Phoca vitulina (harbour seal), Phoca fascista (ribbon seal), Pagophilus groenlandicus (harp seal), Halichoerus grypus (grey seal), Erignathus barbatus (bearded seal), Lobodon carcinophagus (crabeater seal), Ommatophoca rossi (Ross seal), Hydrurga leptonyx (leopard seal), Leptonychotes weddelli (Weddell seal), Monachus monachus (monk seal), Mirounga angustirostris (Northern elephant seal) and Cystohora cristata (hooded seal). Finally, we succeeded in identifying the bone as belonging to M. monachus.

This assignation is based on the particular characteristics of the olecranon, which has a vertical, concave and well-developed edge, and an articular surface consisting of two facets separated by a cusp: an upper facet, formed by a convex face in the cranial zone and a concave face in the ventral zone, which articulate with the distal humerus and extend towards both sides of the olecranon, and a lower concave facet which articulates with the proximal radius and faces towards the lateral zone. This special bone anatomy is characteristic of this species and differentiates it unmistakably from all other phocids (English, 1977; Wyss, 1988). The comparison with remains of modern monk seals has revealed minimal differences which could be due to ontogenetic or intraspecific variability. Fig. 6 shows the fossil bone, in comparison with modern monk seal (from the NHM collection, London), and other seals identified to date at archaeological sites in the northern Iberian Peninsula (H. grypus and P. vitulina).

Similarly, osteometric measurements were taken of the ulnas of all the studied phocids, following Ericson and Storå's methodology (1999) (see Fig. 7). These were compared with the measurements of the discovered specimen (see Table 1) and a principal component analysis also showed that the closest species biometrically is $M$. monachus, which additionally gave the highest coefficient in Pearson's correlation $(r=0.999, p<0.001)$.

Owing to the importance of the find, the bone was dated by C14-AMS, giving a result of $5540 \pm 40 \mathrm{BP}$ (GX-32380). This determination meant that the use of the animal could be attributed to human groups who occupied the cave in the late Mesolithic or early Neolithic. Similarly, DNA was extracted from the bone by Cecilia Anderung at the Natural History Museum in London. Unfortunately, 


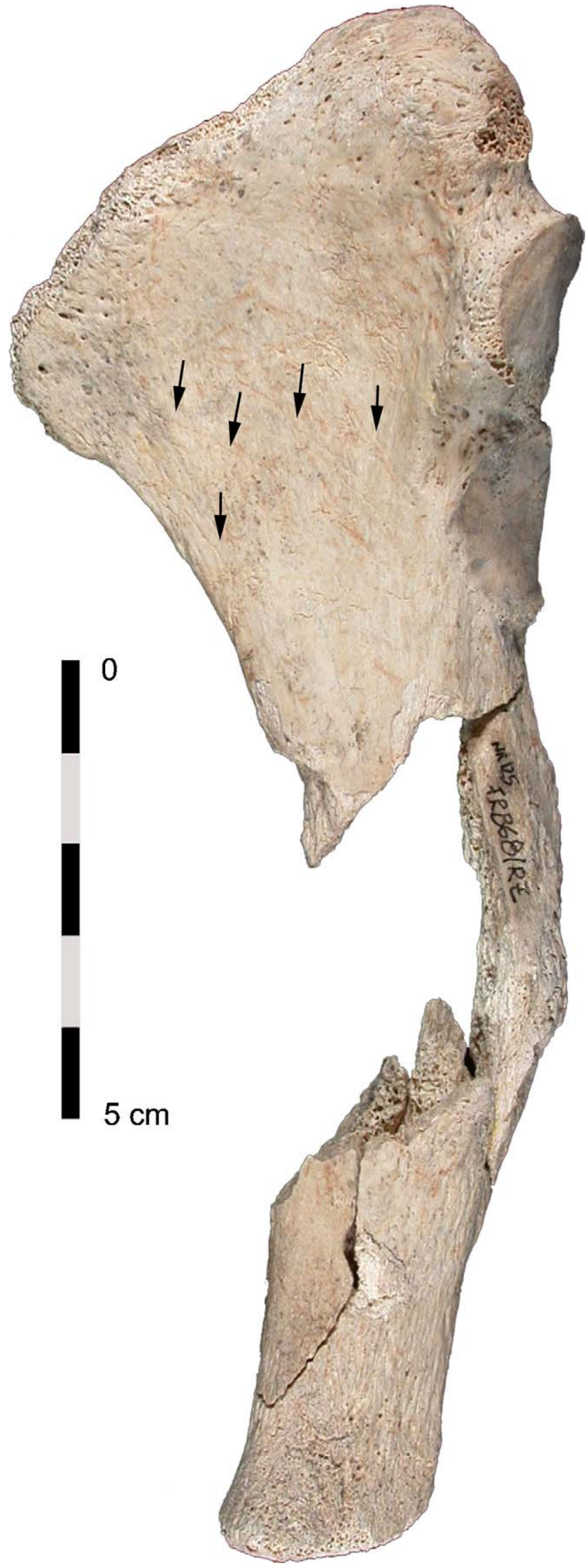

Fig. 4. Ulna of Monachus monachus recovered at La Fragua Cave. The black arrows show the cut marks located in the medial part of the olecranon.

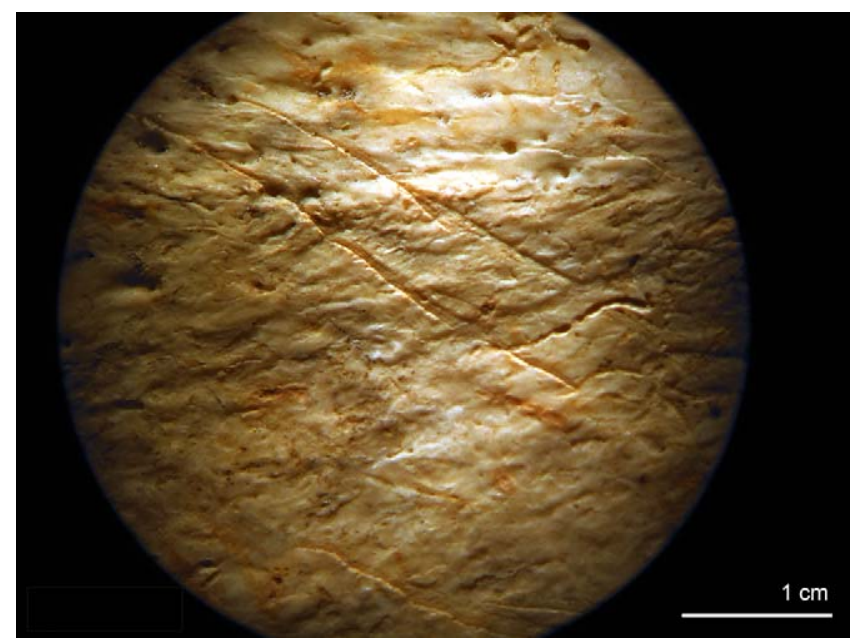

Fig. 5. Detail of $M$. monachus olecranon showing parallel long cut marks on the medial side. The shape and distribution of these cut marks suggest defleshing activity.

because of the poor state of conservation of internal tissues, it was only possible to isolate some sequences of mitochondrial DNA, which clearly belonged to a phocid, but due to their short length, could not be associated with any species in particular.

Regarding monk seal habitat, at present only some 550 individuals are known to survive, most of them located in Greece and the western Sahara (Johnson et al., 2006), although historically (see Fig. 8), before fishing activity reduced its population dramatically, this species occupied a wider geographical area which included the Mediterranean, the Marmara and Black Seas, the Atlantic coast of Africa (Mauritania, Senegal and Gambia), the Canary Islands, the Azores, Madeira and Cape Verde (Johnson and Lavigne, 1999).

Thus, the genus Monachus, made up of the Mediterranean monk seal, the already extinct Caribbean monk seal (Monachus tropicalis) and the Hawaiian monk seal (Monachus schauinslandi), is characterized by living in coastal habitats of temperate to low latitudes (González, 1999). It is able to tolerate high temperatures, with no risk of hyperthermia, by lowering its metabolism during sleep and by exposing its paler ventral area (Marchessaux and Muller, 1987). On the contrary, it avoids colder habitats (González et al., 2002; Dendrinos et al., 2007). This tolerance to warm waters is its distinguishing feature within the family of the pinnipeds, and which is used in the present study as a climatic marker, as its presence in high latitudes could be related to a regime of warm marine currents. Fig. 8 shows the difference in sea surface temperatures (SST) between the Bay of Biscay and the potential habitats of the monk seal.

This species has been sighted very sporadically in the Bay of Biscay in modern times, reaching the coast of Cormier and the south of the Loire estuary (Burguet, 1843; Postel, 1950; BaouinBodin, 1964). From an archaeological point of view, the only remains of monk seal that have been identified on the coast of the northern Iberian Peninsula have been found on the islet of Guidoiro (the Arousa Islands, Pontevedra) and attributed chronologically to the Bronze Age, with a date less than $4000 \mathrm{BP}$ and are probably the result of natural death (Fernández Rodríguez, 2001). These facts reinforce the idea that, unlike the rest of the Late Glacial, monk seal has been able to reach the Cantabrian Sea, at least in certain periods, after the mid-Holocene. In contrast, the Mediterranean coast of the peninsula, where sea temperature is higher and more stable, has provided more evidence of the consumption of this taxon, for example at Gibraltar during the Middle Paleolithic (Stringer et al., 2008) and at Cueva de Nerja in the late Upper Paleolithic (Pérez Ripoll and Raga, 1998). 

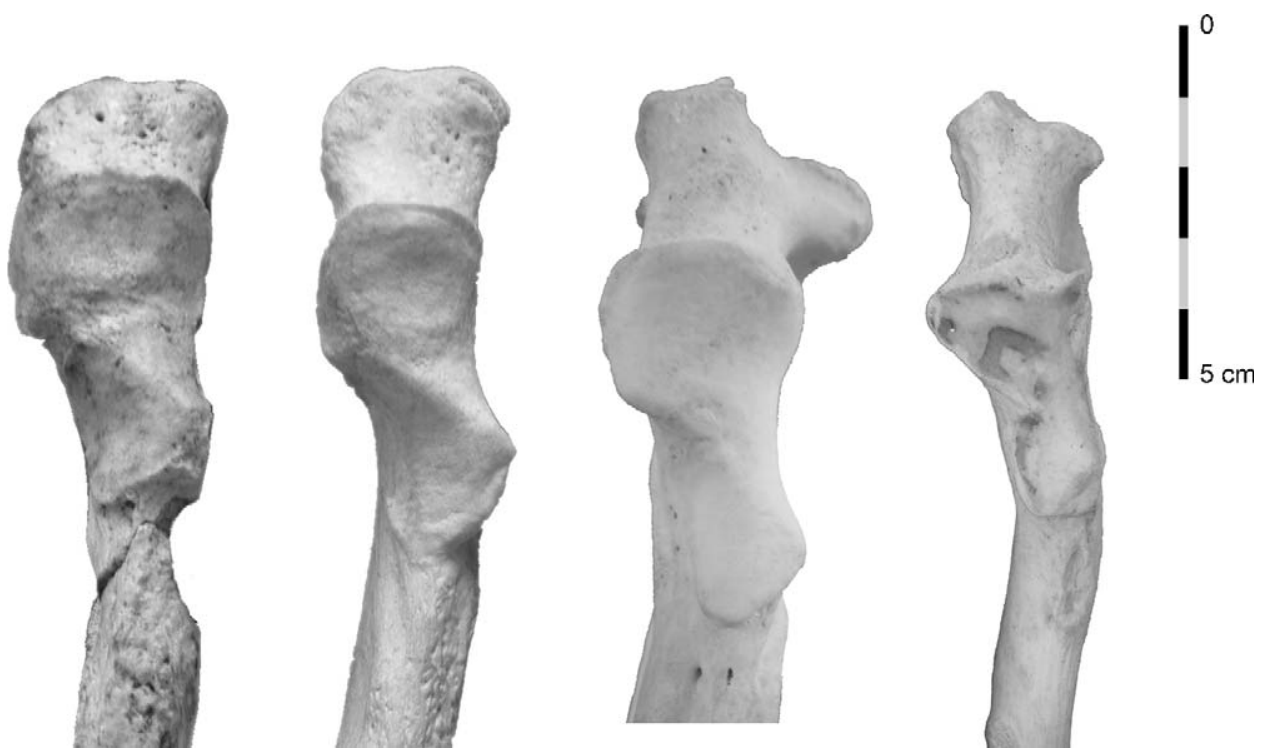

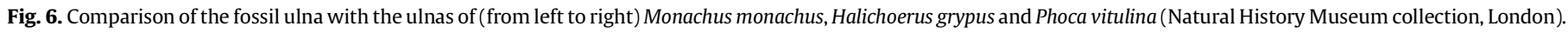

However, the paleoclimatic reconstruction commonly accepted for the mid-Holocene in southwest Europe seems to be in contradiction with the existence of warm waters in the Bay of Biscay. Using pollen information from 510 locations across Europe, transformed into climatic variables through neural network techniques and interpolated spatially and temporally, Davis et al. (2003) devised a detailed reconstruction of the European climate throughout the Holocene. This study updates and improves previous models developed by Prentice et al. (1996) and Cheddadi et al. (1997), with which it shares analogous results.
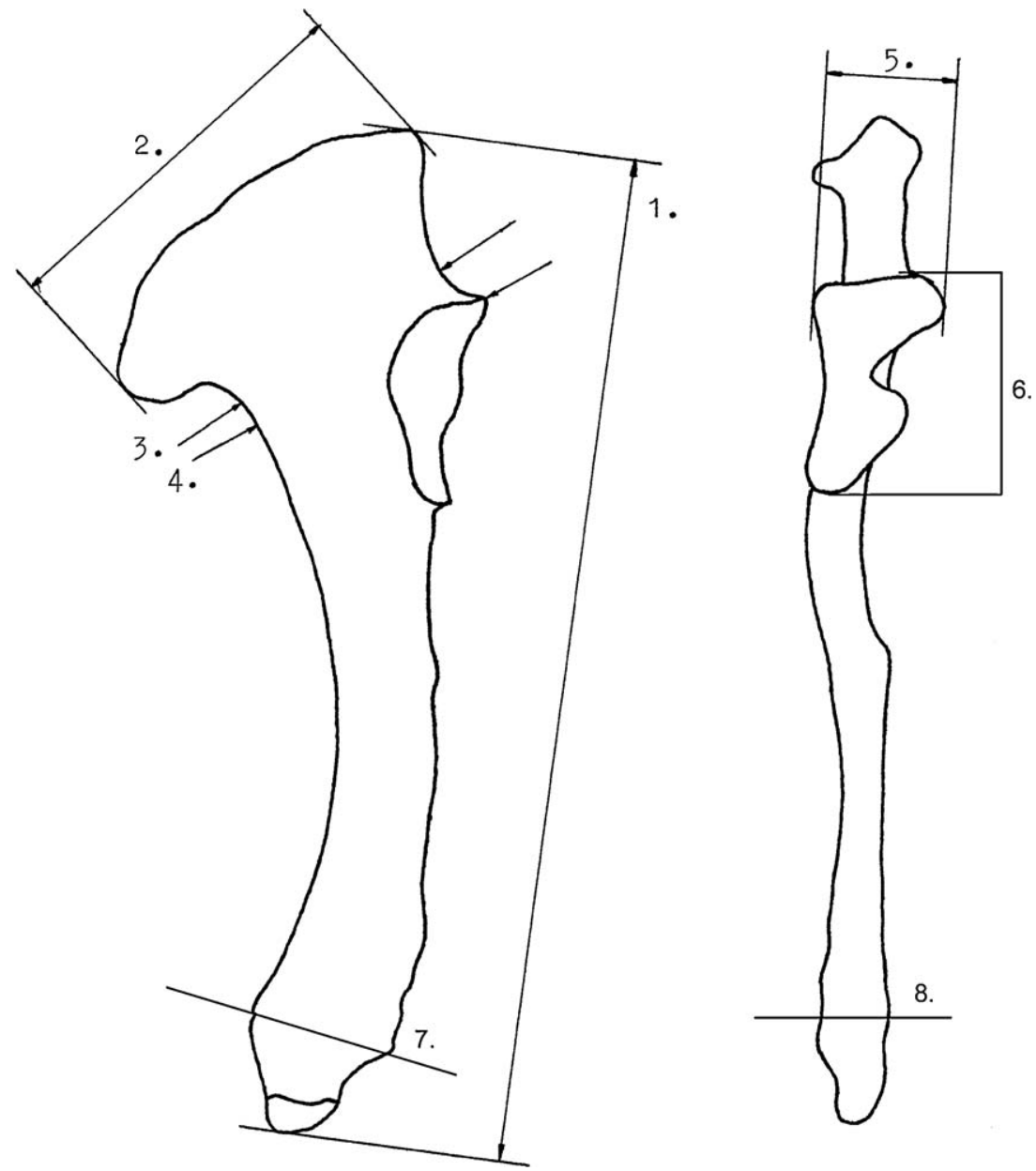

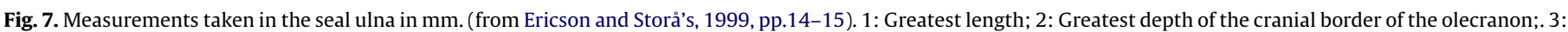

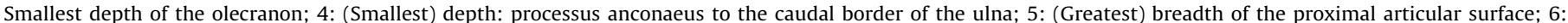

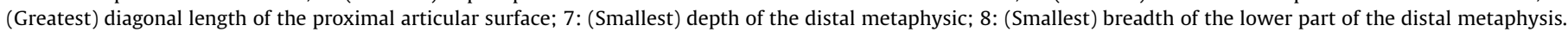


Table 1

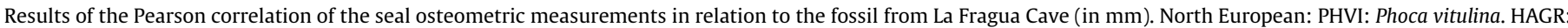

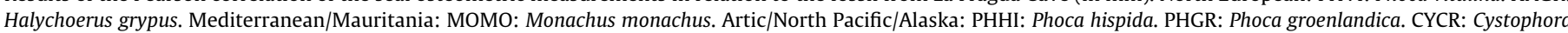

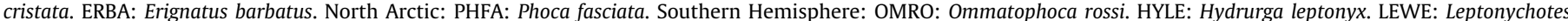
weddelli.

\begin{tabular}{|c|c|c|c|c|c|c|c|c|c|c|c|c|}
\hline Measure & FRAGUA & PHVI & HAGR & MOMO & PHHI & PHGR & CYCR & ERBA & PHFA & OMRO & HYLE & LEWE \\
\hline 1 & 168.2 & 143 & 180 & 168 & 117 & 166 & 195 & 198 & 137 & 163 & 217 & 203 \\
\hline 2 & 72.3 & 56.5 & 69.7 & 76.5 & 36.7 & 52 & 67.7 & 64.9 & 53.8 & 51.2 & 84 & 53.9 \\
\hline 3 & 52.3 & 38.4 & 50.9 & 51.5 & 25 & 37.2 & 50.2 & 45.6 & 33.7 & 49.6 & 73.9 & 45.9 \\
\hline 4 & 55.8 & 39 & 47.7 & 53.1 & 26.3 & 37.7 & 51.2 & 47.3 & 34.8 & 50.3 & 71.9 & 46.3 \\
\hline 5 & 28.3 & 20.7 & 22.8 & 20.7 & 14.3 & 24.8 & 27.4 & 23.5 & 26.9 & 28.8 & 31.9 & 24.9 \\
\hline 6 & 44.6 & 29.4 & 38.7 & 40.7 & 24.1 & 33.6 & 45 & 33.7 & 32.3 & 39.2 & 57.5 & 42.9 \\
\hline 7 & 25 & 20.4 & 21.3 & 22.5 & 14.9 & 20.8 & 26 & 26.3 & 18.1 & 26.3 & 27.4 & 23.8 \\
\hline 8 & 13.5 & 10.5 & 11.5 & 12.8 & 9 & 11 & 14.2 & 14.3 & 12.4 & 15.5 & 19.5 & 14.9 \\
\hline \multicolumn{2}{|c|}{ Pearson correlation } & 0.997 & 0.998 & 0.999 & 0.988 & 0.988 & 0.988 & 0.995 & 0.99 & 0.992 & 0.997 & 0.983 \\
\hline
\end{tabular}

For the mid-Holocene (around $6000 \mathrm{BP}$ ), this study determined that in northern Europe, summer temperatures were about 1 or $1.5^{\circ} \mathrm{C}$ higher than at present, while winter temperatures were similar to the present time in the northeast region and $1{ }^{\circ} \mathrm{C}$ lower in the northwest. This trend is tempered slightly in Central Europe, where temperatures would have been slightly higher during the whole year. For southern Europe, however, and in particular in the southwest (Iberian Peninsula, Italy and southern France), the same database suggests that a mid-Holocene warm phase coeval with the climatic optimum further to the north did not exist. Rather, temperatures during that period are estimated as being lower than today by $1{ }^{\circ} \mathrm{C}$ in summer and $1.5{ }^{\circ} \mathrm{C}$ in winter (see Fig. 9), which would not be possible if SST had been similar to current ones, at least in coastal areas.
This apparent contradiction has been also detected in climatic studies. Thus, the pattern described by palynology has not been simulated accurately by the growing number of numerical models that currently exist to predict variations in future climate, and which use the mid-Holocene as a calibration period. In fact, out of the sixteen climatic models integrated in the first phase of the Paleoclimate Modeling Intercomparison Project (PMIP1) (as described in Bonfils et al., 1998; Joussaume and Taylor, 1995; Joussaume et al., 1999), only two of them reflected an intensity in the growth season lower than at present in this part of the continent (Bonfils et al., 2004).

The discrepancy found between the models and paleoclimate reconstructions has been attributed to uncertainties involved with defining model boundary conditions (Bonfils et al., 2004; Masson
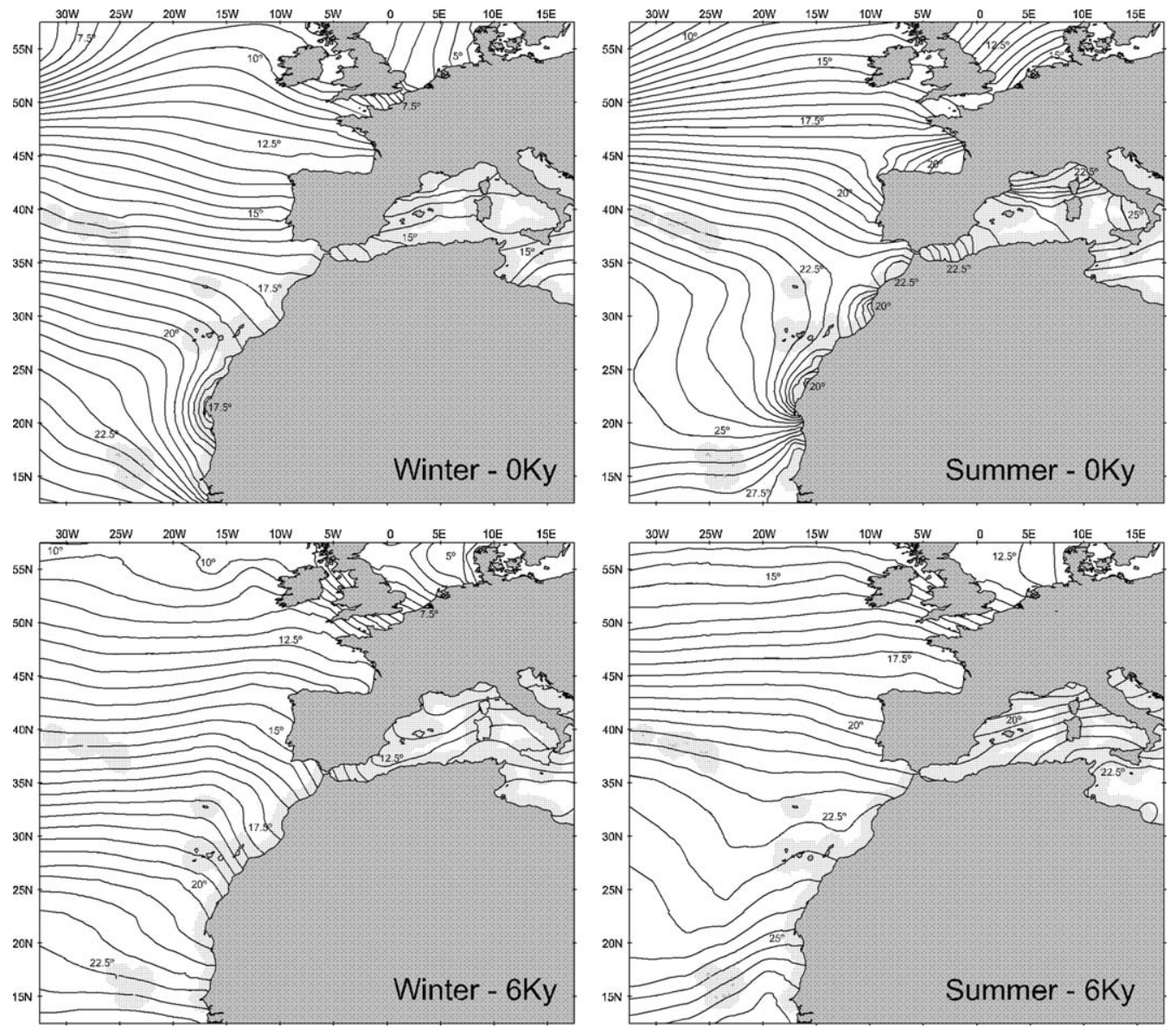

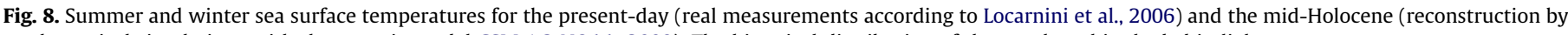
mathematical simulations with the oceanic model CSM 1.2 NOAA, 2009). The historical distribution of the monk seal is shaded in light grey. 
Temperature anomalies derived from pollen data

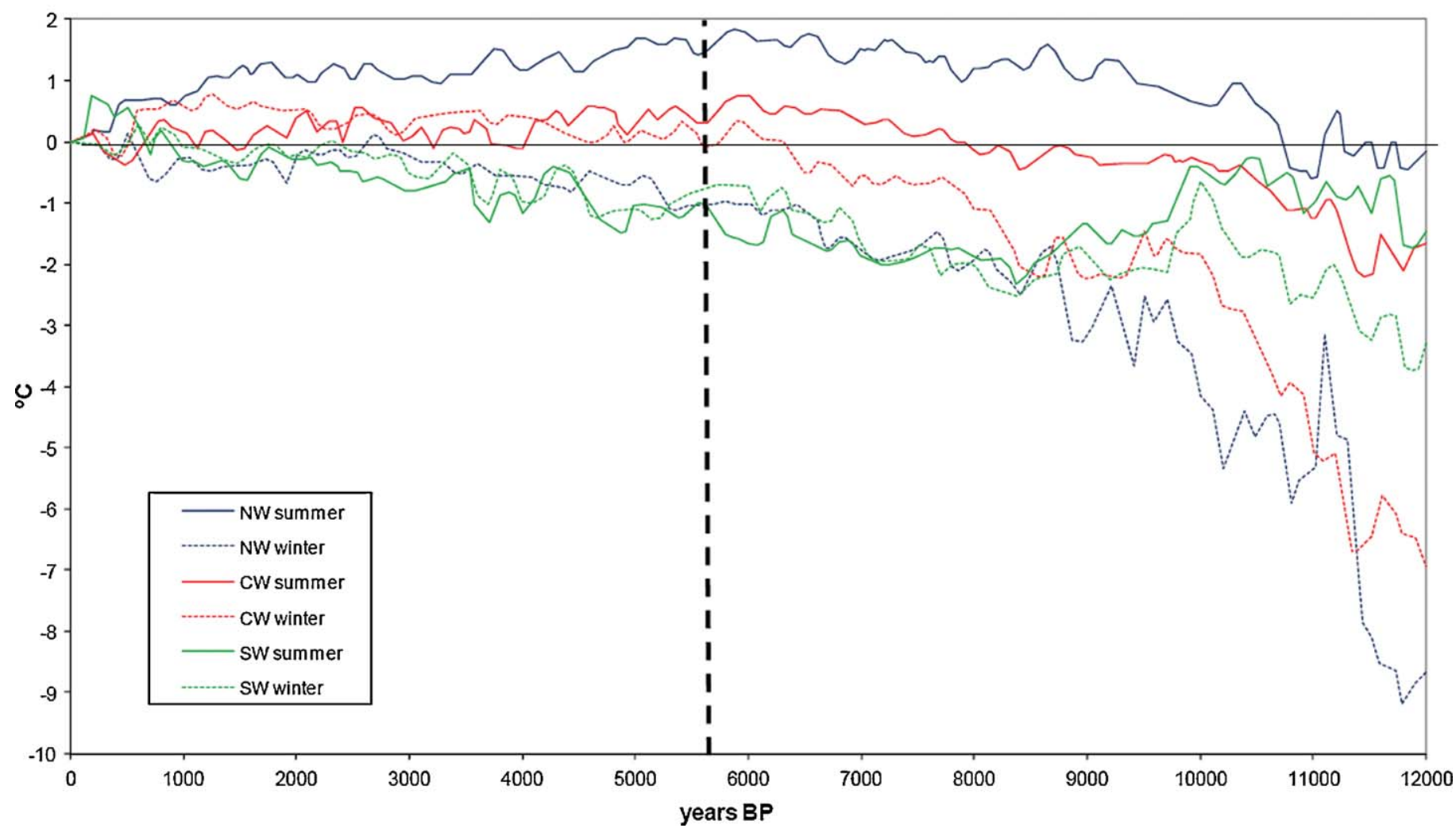

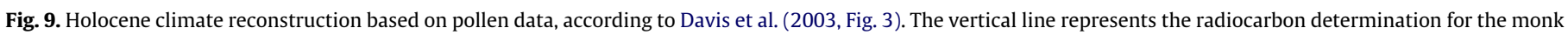
seal remain.

et al., 1999), with preference given to models that link changes in thermohaline circulation with variations in solar insolation and the biosphere (Ganopolski et al., 1998). In fact, the European climate is dominated by westerly winds, as a consequence of its latitude (Fraedrich et al., 1993) and this atmospheric circulation depends on the SST patterns in the Atlantic (Graham et al., 1994). The first set of only atmospheric models assume that SST conditions in the mid-Holocene were similar to the present, as determined by Ruddiman and Mix (1993), leading to warmer conditions in SW Europe. This is not always the case of ocean-atmosphere coupling models, which sometimes point towards cooler temperatures both in the Mediterranean Sea and in the subtropical Atlantic (see for example one of this SST reconstructions during the mid-Holocene in Fig. 8). The pattern is inverted in the North Atlantic, which agrees with the continental results that have finally been obtained, and which may therefore be conditioned by the oceanic regime. To further investigate this matter, Masson et al. (1999) carried out a sensitivity analysis for the different models included in PMIP1 in terms of variations in the Atlantic SST, and found a significant effect on winter temperatures in Europe. This fact is not unusual. Ohgaito and Abe-Ouchi (2009) found a similar influence of SST in the simulation of mid-Holocene Asian monsoons.

In a second phase of the PMIP (Brewer et al., 2006), 26 models with different levels of complexity were tested (using atmosphere, atmosphere-ocean coupling, and atmosphere-ocean-vegetation coupling). The results improved slightly on those of PMIP1, without succeeding in simulating the intensity of the variations in southwest Europe, but clearly showing the influence of ocean circulation on continental conditions all over the world (Braconnot et al., 2007). SST is then a key factor and potential source of model bias that requires more efforts to be confidently settled.

Accordingly, it is reasonable to envisage the possibility that the terrestrial proxies in southwest Europe are not fully representative for the mid-Holocene, at least in coastal areas. The discovery of the monk seal ulna reported here would then strengthen this hypothesis.

\section{Discussion}

The Mediterranean monk seal is currently one of the most threatened marine mammal species and is classified as "critically endangered" by the World Conservation Union; it is included in Appendix I of the Convention on International Trade in Endangered Species (UNEP//MAP, 1994). Consequently, every new information regarding its potential habitat or historic geographical range is considered crucial for its conservation. However, the discovery of this seal species at a prehistoric site in northern Spain has an added importance, as it suggests the possibility that it occurred commonly in this region and it was regularly exploited when warmer or equal environmental conditions than at present might have prevailed, caused by the existence of a regime of favorable oceanic currents. This could have important climatic implications. In the Baltic Sea, for example, changes in the numbers of phocids have been correlated with major alterations in environmental conditions (Schmölcke, 2008). The northern Spanish coast, while receiving currents from the Northeast Atlantic, is on the southern boundary of the distribution of northern phocid species, being an important and sensitive area in understanding the environmental changes which occur in the Holocene as a result of modifications in the circulation of sea currents, both in the long-term and in the case of sudden instabilities (Alley et al., 1997; Barber et al., 1999). These changes would have had repercussions on prehistoric subsistence strategies (Estévez, 2005; Cueto et al., 2006).

The fact that the presence of monk seal in the Cantabrian Sea fits badly within the palynological paleoclimate reconstruction is also relevant, above all given the failure of climate modes to resemble its conclusions in southwest Europe, and so, more climatic proxies are 

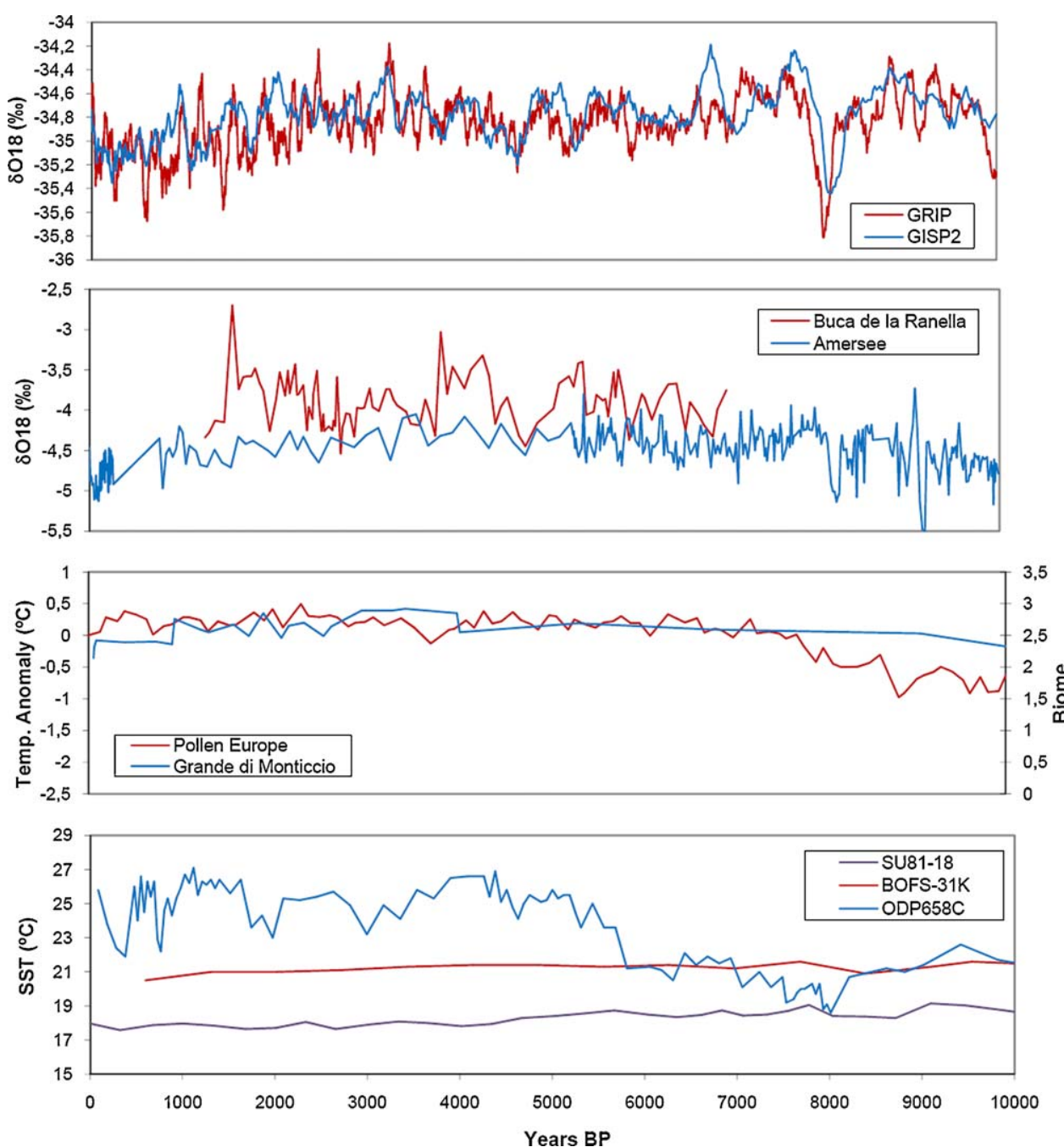

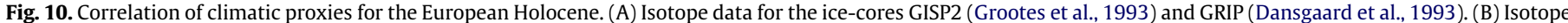

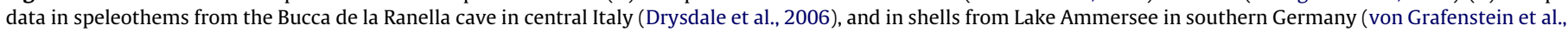

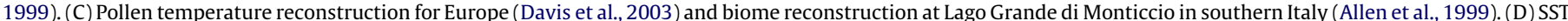

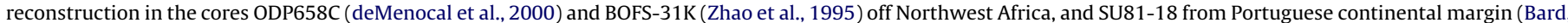
2002). The dashed vertical line represents the radiocarbon determination of the monk seal remains.

needed to enlighten the discussion. In this sense, the studies carried out on charcoal (Terral and Mengual, 1999), speleothems (Drysdale et al., 2006) and lake levels (Harrison and Digerfeldt, 1991; Roca and Julia, 1997) would support palynological conclusions (see Fig. 10), as would do isotope records from the Arctic acting as a general framework (Dansgaard et al., 1993; Grootes et al., 1993) and Central Europe (von Grafenstein et al., 1999). In contrast, the scarce data available for the marine environment contradict this trend and suggest a possible higher SST in this region during the period being studied (Ariztegui et al., 2000; Emeis et al., 2000; Bard, 2002; Marchal et al., 2002; Myers and Rohling, 2000; Rohling and De Rijk, 1999), within a scenario of global warming in the North Atlantic (Bond et al., 1997). It is interesting to note that the biome reconstruction based on pollen evidence from Lago Grande di Monticcio in southern Italy (Allen et al., 1999) indicate slightly warmer climatic conditions in the mid-Holocene, in contrast with the conclusions of Davis et al. (2003).

In the case of the Cantabrian Coast it is reasonable to consider that maritime proxies are more trustworthy than terrestrial ones. In fact, the paleoclimate in northern Spain has always felt the strong influence of the thermo-regulating effect of the Bay of Biscay and the sea currents reaching the area, which would have made intense human occupation possible, above all during the Upper Paleolithic (Straus, 2005). The Cantabrian Coast, being a narrow coastal strip between the Cantabrian Cordillera (with peaks that reach 1500-2000 masl) and the sea, separated only by $30-50 \mathrm{~km}$, is also nowadays an exception in the Iberian Peninsula, enjoying a rather humid and temperate climate, highly affected by oceanic currents. The continental platform to the northwest and north of the Iberian Peninsula (between 42 and $45^{\circ} \mathrm{N}$ ) is located precisely on the boundary separating the subpolar and subtropical circulation in the Northeast Atlantic (Pollard et al., 1996). The existing currents carry to the Bay of Biscay the so-called Eastern North Atlantic Central Water of Subpolar mode (ENACW ${ }_{\mathrm{sp}}$ ) and of subtropical mode $\left(E^{2} A C W_{s t}\right)$. These masses of water, originating in the Celtic Sea $\left(46^{\circ} \mathrm{N}\right)$ and near the Azores $\left(35^{\circ} \mathrm{N}\right)$ respectively, are clearly different in their thermohaline characteristics, as the latter has a higher temperature and salinity than the former (Fiuza, 1984; Harvey, 1982; Ríos et al., 1992).

Both masses dominate alternatively the most superficial oceanic layer in the Bay of Biscay. The boundary between them is generally located around Cape Finisterre $\left(43^{\circ} \mathrm{N}\right)$ but may vary, depending on particular climatic conditions (Fraga et al., 1982; Fraga, 1991; Pérez et al., 1993). In fact, a powerful current has been described, which pushes waters from the ENACW st $_{\text {along the }}$ coasts of Portugal and Spain as far as the easternmost part of the Bay of Biscay in winter and early spring. This is a common phenomenon on eastern oceanic margins (Neshyba et al., 1989) 
and has been called the Iberian Poleward Current (Peliz et al., 2003), the Portugal Coastal Counter Current (Álvarez-Salgado et al., 2003) and the Christmas Current (García-Soto et al., 2002).

The causes that would lead to a reinforcement of this current, and consequently a greater prevalence of warm waters in the Bay of Biscay, are still being researched. However, general consensus attributes the main driving force to the large-scale meridional density gradient, through the Joint Effect of Baroclinicity and Relief (Coelho et al., 1999; Huthnance, 1984; Peliz et al., 2005; Pingree and New, 1989; Lazure et al., 2008), where the difference in the SST in subpolar and subtropical latitudes is a good indicator of the intensity of the phenomenon that can be expected. This difference can be correlated with the existence of a South-North atmospheric pressure gradient, represented by the NAO (North Atlantic Oscillation, according to García-Soto et al., 2002; Pérez et al., 2000) or the EA indices (East Atlantic, according to GonzálezNuevo and Nogueira, 2005). Thus, the existence of persistent high pressures in the subtropical zone would favor the warming of the sea surface and the existence of a water density gradient forcing the arrival of the ENACW st $_{\text {to }}$ the Bay of Biscay.

Another possibility that could have increased SST in the Bay of Biscay during the mid-Holocene is the strengthening of the subtropical gyre circulation in the open North Atlantic. This phenomenon could have carried more subtropical waters to the western Iberian Margin as a spin-off from the North Atlantic Drift Current (Rossby, 1996), leading to a global amelioration of European climate (Bryden et al., 2005; Duplessy, 1999; Sutton and Hodson, 2005).

Mechanisms of this type could have been the cause of migrations of monk seal colonies, or isolated individuals, to the eastern part of the northern Spanish coast, which would indicate that oceanographic conditions in the mid-Holocene were at least similar to the present day, with important climate implications for southwest Europe. In this respect, the oxygen and carbon isotope records in benthic foraminifera in the Ría de Muros (NW Iberia) indicate a prevalence of ENACW st $_{\text {during the }}$ first part of the Holocene (8200-4000 BP) identified with the weakening of upwelling phenomena (Pena et al., 2007). This correlates well with the SST anomalies detected in oceanic cores off the African coast $\left(20.75^{\circ} \mathrm{N}\right.$, in deMenocal et al., 2000; $19^{\circ} \mathrm{N}$ in Zhao et al., 1995$)$ and the Portuguese coast $\left(37.77^{\circ} \mathrm{N}\right.$, in Bard, 2002). Hence, as is shown in Fig. 9, the scarce oceanic data for the subtropical Atlantic would be compatible with the hypothesis proposed here.

In addition, the presence of the monk seal in northern Spain coincides with the observations made by Vega del Sella (1916, $1921,1923)$ about the substitution of cold-water mollusc species (Littorina littorea) by temperate-water ones (Osilinus lineatus [=Trochus lineatus]) in the early Holocene. These early data were confirmed by subsequent research that showed both the fact of the substitution and its abrupt nature. $O$. lineatus is practically absent in Late Pleistocene sites along the Cantabrian Coast, where $L$. littorea is ubiquitous. At El Perro rockshelter, at about $800 \mathrm{~m}$ WSW from La Fragua and also in the cliffs over present day sea, in Azilian occupations dated of $10,160 \pm 110 \mathrm{BP} 53 \%$ of the malacofaunal NMI $(=14.541)$ are L. littorea, and Osilinus represent less than $1 \%$; in the overlying Mesolithic, deposit, dated of $9.260 \pm 110 \mathrm{BP}$, Osilinus reaches $12.3 \%$ and Littorina represents $0.3 \%$ (malacofaunal $\mathrm{NMI}=15.484)$. At La Fragua, Level $3(9.600 \pm 140)$, dominated by land snails, include $L$. littorea $(\mathrm{NMI}=21)$ and one single individual of Osilinus, while the upper Level 1, dated in its preserved part between $7.530 \pm 70$ and $6.650 \pm 120 \mathrm{BP}$, the NMI numbers are reversed: 1 for Littorina and 542 for Osilinus. The same pattern is common across the Cantabrian Coast, as noted for different researchers working on regional Mesolithic (Clark, 1983: 110-119; González Morales, 1982: 70-77; Gutiérrez Zugasti, 2009).
Similarly, its chronology is near the Holocene transgression maximum, dated locally for the western coast of Cantabria by Mary et al. $(1975,1977)$ at between 5800 and $5300 \mathrm{BP}$, when sea level reached a height above that of the present. At La Jerra (Oyambre, Cantabria), the study of several peat bogs and their dating by radiocarbon has allowed to reconstruct the sea level movements during the last part of the Atlantic period: ca. $5850 \pm 200 \mathrm{BP}$ (Gif-3050), arborescent vegetation covered an area located at $135 \mathrm{~m}$, at least, of present shoreline, as shown by a peat deposit located at $2.50 \mathrm{~m}$ below the maximum level of the present beach. After that date, the sea invaded the area to the valley of Oyambre, from where the waters retired ca. $5300 \pm 120 \mathrm{BP}$ (Gif-2917) (date of a peat bog deposited over the layer of sands and cobbles left by the transgression), reaching in their descent a lower level than today, a fact verified by a peat bog located at $25 \mathrm{~m}$ from present day coastline, and dated of $5250 \pm 90 \mathrm{BP}$ (Gif-1893). Later, a new sea level rise over the present day height submerged the area. The existence of two transgressive phases later than the basal date $(5880 \pm 130 \mathrm{BP}$, Gif-2635) has been verified in another nearby peat bog by the presence of marine planctonic remains in two different levels (Mary, 1975). These possible two transgressive episodes have been cited by other authors, although with different chronologies, and a Holocene episode with sea levels higher than present has been also described in the French Atlantic coast (Cearreta et al., 1992).

This also agrees with the evolution observed in the macromammalian fauna. In the case of La Fragua Cave, ibex, an ungulate usually related to colder climate reduced significantly from Late Pleistocene (23.8\% in Level 4) to early Holocene (3.06\% in Level 1), while wild boar, an animal more suited for temperate environments, increased from $0.41 \%$ in Level 4 to $36.7 \%$ in Level 1 (Marín, 2004). The pattern is similar for the whole Cantabrian Coast (Marín, 2009). Remarkably, while reindeer is commonly found in this region during the Late Glacial Maximum, it vanishes from Cantabrian faunas with the arriving of the Holocene (Straus, 1992).

In short, the find of this warm-water species at northern latitude during the mid-Holocene, supports the possibility that the regime of currents in the Bay of Biscay about 6000 years ago was similar to, or even more benign than, at present, with the implications this has for the oceanic circulation in the North Atlantic. If this was true, the climate of coastal areas would have benefited from the thermoregulation effect of the sea, as a result of

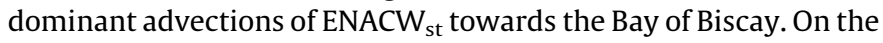
other hand, the prevalence of positive phases in the NAO and EA indices would have a highly significant effect on the European climate of inland areas, possibly causing milder conditions in all or part of the continent (Hurrell, 1995; Gladstone et al., 2005; Rowell and Rodwell, 1999). This aspect should be taken into account in the calibration of mid-Holocene climate models to avoid forcing them and reducing their predictive ability.

\section{Conclusions}

During the zooarchaeological analysis of faunal remains from La Fragua Cave in Cantabria and after careful refitting of bone fragments, a $M$. monachus ulna with signs of human consumption was identified and dated to the mid-Holocene. This discovery is outstandingly significant for several reasons:

(1) It is a species currently in critical danger of extinction. Therefore an understanding of the full range of its past habitat could improve our understanding of the species, its ecological requirements and potential present-day range.

(2) If the identified individual was in fact carried on warm sea currents, as has occurred with modern individuals cited occasionally in the literature, its presence indicates that the present regime of currents in the Bay of Biscay would already 
have been established about 6000 years ago. This should be taken into account during the calibration of modern climate models, given the important influence of the Atlantic Ocean in the climate of Europe.

(3) The demonstration of the existence of warm coastal waters on the northern coast of the Iberian Peninsula, during the climatic episode of global warming in the mid-Holocene, contradicts the data from terrestrial proxies that suggest the area was relatively cooler. This is an important point for the interpretation of the productive changes recorded in the region at that time.

(4) The identification of this specimen opens the possibility of further fieldwork to identify the presence of colonies of Monk Seals in the numerous sea caves near La Fragua Cave, which remain unexplored and which are only accessible by sea. This potential is based on the moderate fall in sea level which would have occurred after the transgression maximum in the midHolocene, preserving contemporaneous beach remains inside the caves.

\section{Acknowledgements}

This research would not have been possible without the help of several European scholars and institutions. François Poplin (MNHN, Paris) allowed us to consult the complete osteological collection of the museum as did Richard Sabin at the Natural History Museum (NHM), London. The Oceanographic Museum of Monaco kindly lent us two monk seal ulnas and Luis Mariano González from the Dirección General del Medio Natural y Política Forestal (MARM, Spain) provided us with monk seal samples from the Mauritanian colony. Cecilia Anderung (NHM, London) undertook the DNA analysis. K. Aaris-Sørensen, Curator of Zoological Museum of the University of Copenhagen and M. Pérez-Ripoll (University of Valencia) helped us with the identification. Finally, Mark Lewis (NHM, London) made some corrections to the English. ABM wants to thank David Ocio for his support. Her research was funded with a Postdoctoral Fellowship from the Educational Department of The Basque Country Government (Spain).

\section{References}

Allen, J.R.M., Brandt, U., Brauer, A., Hubberten, A.-H., Huntley, B., Keller, J., Kraml, M., Mackensen, A., Mingram, J., Negendank, J.F.W., Nowaczyk, N.R., Oberhänsli, H., Watts, W.A., Wulf, S., Zolitschka, B., 1999. Rapid environmental changes in southern Europe during the last glacial period. Nature 400, 740-743.

Alley, R.B., Mayewski, P.A., Sowers, T., Stuiver, M., Taylor, K.C., Clark, P.U., 1997. Holocene climatic instability-a prominent, widespread event 8200 years ago. Geology 25, 483-486.

Altuna, J., 1976. Los Mamíferos del yacimiento prehistórico de Tito Bustillo (Asturias). In: Moure Romanillo, J.A., Cano Herrena, M. (Eds.), Excavaciones en la cueva de Tito Bustillo (Asturias). Instituto de Estudios Asturianos, Asturias, pp. $149-154$.

Altuna, J., 1986. The mammalian faunas from the Prehistoric Site of La Riera. In: Straus, L.G., Clark, G. (Eds.), La Riera Cave. Stone Age Hunter-Gatherer Adaptations in Northern Spain. Anthropological Research Paper 36. Arizona. pp. 237 274, 421-479, 481-497.

Altuna, J., Straus, L.G., 1976. The Solutrean of Altamira: the artifactual and faunal evidence. Zephyrus 26, 175-182.

Álvarez-Salgado, X.A., Figueiras, F.G., Pérez, F.F., Groom, S., Nogueira, E., Borges, A.V. Chou, L., Castro, C.G., Moncoiffé, G., Ríos, A.F., Miller, A.E.J., Frankignoulle, M., Savidge, G., Wollast, R., 2003. The Portugal coastal counter current off NW Spain: new insights on its biogeochemical variability. Progress in Oceanography 56, 281-321.

Ariztegui, D., Asioli, A., Lowe, J.J., Trincardi, F., Vigliotti, L., Tamburini, F., Chondrogianni, C. Accorsi, C.A., Mazzanti, M.B., Mercuri, A.M., Van der Kaars, S., McKenzie, J.A., Oldfield, F., 2000. Palaeoclimate and the formation of sapropel S1: inferences from Late Quaternary lacustrine and marine sequences in the central Mediterranean region. Palaeogeography, Palaeoclimatology, Palaeoecology 158 (3-4), 215-240.

Baouin-Bodin, J., 1964. Capture de phoque moine dans l'Atlantique. Mammalia 28 (3), 522.

Barber, D.C., Dyke, A., Hillaire-Marcel, C., Jennings, A.E., Andrews, J.T., Kerwin, M.W. Bilodeau, G., McNeely, R., Southon, J., Morehead, M.D., Gagnon, J.-M., 1999. Forcing of the cold event of 8200 years ago by catastrophic drainage of Laurentide lakes. Nature 400, 344-348.
Bard, E., 2002. Climate shock: abrupt climate changes over millennial time scales. Physics Today 55 (12), 32-38.

Behrensmeyer, A.K., 2006. Climate change and human evolution. Science 311 (5760), 476-478.

Bond, G., Showers, W., Cheseby, M., Lotti, R., Almasi, P., deMenocal, P., Priore, P. Cullen, H., Hajdas, I., Bonani, G., 1997. A pervasive millennial-scale cycle in North Atlantic Holocene and glacial climates. Science 278 (5341), 1257-1266.

Bonfils, C., Lewden, D., Taylor, K.E., 1998. A summary documentation of the PMIP models, PCMDI Report. http://www-lsce.-cea.fr/pmip.

Bonfils, C., Noblet-Ducoudré, N., de Guiot, J., Bartlein, P., 2004. Some mechanisms of mid-Holocene climate change in Europe, inferred from comparing PMIP models to data. Climate Dynamics 23, 79-98.

Braconnot, P., Otto-Bliesner, B., Harrison, S., Joussaume, S., Peterchmitt, J.-Y., AbeOuchi, A., Crucifix, M., Driesschaert, E., Fichefet, T.H., Hewitt, C.D., Kageyama, M. Kitoh, A., Lâiné, A., Loutre, M.-F., Marti, O., Merkel, U., Ramstein, G., Valdes, P., Weber, S.L., Yu, Y., Zhao, Y., 2007. Results of PMIP2 coupled simulations of the Mid-Holocene and Last Glacial Maximum-Part 1. Experiments and large-scale features. Climate of the Past Discussion 3, 261-277.

Brewer, S., Guiot, J., Torre, F., 2006. Mid-Holocene climate change in Europe: a datamodel comparison. Climate of the Past Discussion 2, 1155-1186.

Brovkin, V., Ganopolski, A., Claussen, M., Kubatzki, C., Petoukhov, V., 1999. Modelling climate response to historical land cover change. Global Ecology and Biogeography 8 (6), 509-517.

Bryden, H.L., Longworth, H.R., Cunningham, S.A., 2005. Slowing of the Atlantic meridional overturning circulation at $25^{\circ} \mathrm{N}$. Nature 438, 655-657.

Burguet, H., 1843. Melanges d'histoire naturelle pour servir ä la faune du departement de la Gironde. Actes de la Societé Linnéenne Bordeaux 13, 300318.

Cearreta, A., Edeso, J.M., Ugarte, F.M., 1992. Late Quaternary sea-level changes in the Bay of Biscay. In: Cearreta, A., Ugarte, F.M. (Eds.), The Late Quaternary in the Western Pyrenean Region. Universidad del País Vasco, Vitoria, pp. 57-94.

Cheddadi, R., Yu, G., Guiot, J., Harrison, S., Prentice, I.C., 1997. The climate of Europe 6000 years ago. Climate Dynamic 13, 1-9.

Clark, G.A., 1983. Una perspectiva funcionalista en la Prehistoria de la región cantábrica. Homenaje al Profesor Martín Almagro Basch I. Ministerio de Cultura, Madrid, pp. 155-170.

Claussen, M., Mysak, L.A., Weaver, A.J., Crucifix, M., Fichefet, T., Loutre, M.F., Weber, S.L., Alcamo, J., Alexeev, V.A., Berger, A., Calov, R., Ganopolski, A., Goose, H., Lohmann, G., Lunkeit, F., Mokhov, I.I., 2002. Earth system models of intermediate complexity: closing the gap in the spectrum of climate system models. Climate Dynamics 18 (7), 579-586.

Coelho, H.S., Neves, R.R., Leitao, P.C., Martins, H., Santos, A.P., 1999. The slope current along the western European margin: a numerical investigation. Boletín del Instituto Español de Oceanografía 15 (1-4), 61-72.

Corchón, M., Mateos, A., Alvarez, E., Peñalver, E., Delclòs, X., van der Made, J., 2008. Ressources complémentaires et mobilité dans le Magdalénien cantabrique. Nouvelles données sur les mammifères marins, les crustacés, les mollusques et les roches organogènes de la Grotte de Las Caldas (Asturies, Espagne). L'Anthropologie 112 (2), 284-327.

Crucifix, M., Loutre, M.F., Tulkens, P., Fichefet, T., Berger, A., 2002. Climate evolution during the Holocene: a study with an Earth System model of intermediate complexity. Climate Dynamics 19 (1), 43-60

Cueto, M., Marín, A.B., Estévez, J., 2006. Apuntes para un cambio de ritmo en la explicación del cambio al Postglaciar. Munibe 57 (1), 399-410.

Dansgaard, W., Johnsen, S.J., Clausen, H.B., Dahl-Jensen, D., Gundestrup, N.S. Hammer, C.U., Hvidberg, C.S., Steffensen, J.P., Sveinbjörnsdottir, A.E., Jouzel, J., Bond, G., 1993. Evidence for general instability of past climate from a $250-\mathrm{kyr}$ Ice-core record. Nature 364, 218-220.

Davis, B.A.S., Brewer, S., Stevenson, A.C., Guiot, J., 2003. The temperature of Europe during the Holocene reconstructed from pollen data. Quaternary Science Reviews 22, 1701-1716.

deMenocal, P., Ortiz, J., Guilderson, T.P., Sarnthein, M., 2000. Coherent high- and low-climate variability during the Holocene warm period. Science $288,2198-$ 2202.

Dendrinos, P., Karamanlidis, A.A., Kotomatas, S., Legakis, A., Tounta, E., Matthiopoulos, J., 2007. Pupping habitat use in the Mediterranean monk seal: a long term study. Marine Mammal Science 23 (3), 615-628.

Drysdale, R., Zanchetta, G., Jellstrom, J., Maas, R., Fallick, A., Pickett, M., Cartwright, I., Piccini, L., 2006. Late Holocene drought responsible for the collapse of Old World civilizations is recorded in an Italian cave flowstone. Geology 34 (2), 101-104.

Emeis, K.C., Struck, U., Schulz, H.M., Rosenberg, R., Bernasconi, S., Erlenkeuser, H., Sakamoto, T., Martinez-Ruiz, F., 2000. Temperature and salinity variations of Mediterranean Sea surface waters over the last 16,000 years from records of planktonic stable oxygen isotopes and alkenon e unsaturation ratios. Palaeogeography, Palaeoclimatology, Palaeoecology 158, 259-280.

Duplessy, J.C., 1999. Oceanography: climate and the gulf stream. Nature 402, 593 595.

English, A.W.M., 1977. Structural correlates of forelimb function in fur seals and sea lions. Journal of Morphology 151 (3), 325-352.

Ericson, P.G.P., Storå, J., 1999. A Manual to the Skeletal Measurements of the Seal Genera Halichoerus and Phoca (Mammalia: Pinnipedia). Department of Vertebrate Zoology, Swedish Museum of Natural History, Stencilm, Stockholm.

Estévez, J., 2005. Catástrofes en Prehistoria. Editorial Bellaterra.

Fiuza, A.F.G., 1984. Hidrologia e dinámica das aguas costeiras de Portugal. Ph.D. Thesis, University of Lisbonne. Portugal. 
Foley, R.A., 1994. Speciation, extinction, and climatic change in hominid evolution. Journal of Human Evolution 26, 277-289.

Fraedrich, K., Bantzer, C., Burkhardt, U., 1993. Winter climate anomalies in Europe and their associated circulation at $500 \mathrm{hPa}$. Climate Dynamics 8, 161-175.

Fraga, F., Mouriño, C., Manriquez, M., 1982. Las masas de agua en la costa de Galicia: junio-octubre. Resultados Expediciones Científica 10, 51-77.

Fraga, F., 1991. El afloramineto costero em la costa atlántica de la Penísula Ibérica. Revista Académica galega de Ciencias 10, 142-152.

Fernández Rodríguez, C., 2001. Informe sobre los restos óseos de macromamíferos del yacimiento de Guidoiro Areoso (Pontevedra). Technical Report. Servicio de Arqueometría. Universidade de Santiago de Compostela, La Coruña.

Ganopolski, A., Kubatzki, C., Claussen, M., Brovkin, V., Petoukhov, V., 1998. The influence of vegetation-atmosphere-ocean interaction on climate during the mid-Holocene. Science 280 (5371), 1916-1919.

Ganopolski, A., Rahmstorf, S., 2001. Rapid changes of glacial climate simulated in a coupled climate model. Nature 409 (6817), 153-158.

García-Soto, C., Pingree, R.D., Valdés, L., 2002. Navidad development in the southern Bay of Biscay: climate change and swoddy structure from remote sensing and in situ measurements. Journal of Geophysical Research 107, 1-29.

Genty, D., Blamart, D., Ouahdi, R., Gilmour, M., Baker, A., Jouzel, J., Van-Exter, S. 2003. Precise dating of Dansgaard-Oeschger climate oscillations in Western Europe from stalagmite data. Nature 421, 833-837.

Gladstone, R.M., Ross, I., Valdes, P.J., Abe-Ouchi, A., Braconnot, P., Brewer, S Kageyama, M., Kitoh, A., LeGrande, A., Marti, O., Ohgaito, R., Otto-Bliesner, B., Peltier, W.R., Vettoretti, G., 2005. Mid-Holocene NAO: a PMIP2 model intercomparison. Geophysical Research Letters 32, L16707.

González, L.M., 1999. Foca monje del Mediterráneo. Monachus monachus (Hermann, 1779). Galemys 11 (1), 3-16.

González, L.M., Heredia, B., Araujo, A., Robinson, I., Worms, J., Miller, P.S., Seal, U. 2002. Population and Habitat Viability Assessment for the Mediterranean Monk Seal (Monachus monachus) in the Eastern Atlantic. Workshop Report. IUCN/SSC Conservation Breeding Specialist Group, Apple Valley, MN.

González Morales, M.R., 1982. El Asturiense y otras culturas locales. La explotación de las áreas litorales de la Región Cantábrica en los tiempos epipaleolíticos. Centro de Investigación y Museo de Altamira, Santander.

González Morales, M.R., 2000. La Prehistoria de las Marismas: Excavaciones en la Cueva de La Fragua (Santoña), Campañas de 1990, 1991, 1993, 1994 y 1996. In: Ontañón, R. (Ed.), Actuaciones arqueológicas en Cantabria, 1984-1999. Gobierno de Cantabria, Santander, pp. 177-179.

González Morales, M.R., García Codrón, J.C., Morales Muñiz, A., 1992. El Bajo Asón del X al V milenio BP: cambios ambientales, económicos y sociales en el paso a la Prehistoria Reciente. In: Cearreta, A., Ugarte, F.M. (Eds.), The Late Quaternary in the Western Pyrenean Region. Universidad del País Vasco, Vitoria, pp. 333-342.

González-Nuevo, G., Nogueira, E., 2005. Intrusions of warm and salty waters onto NW and N Iberian shelf in early spring and its relationship to climate variability. Journal of Atmospheric and Ocean Science 10 (4), 361-375.

Graham, N.E., Barnett, T.P., Wilde, R., 1994. On the roles of tropical and mid-latitude SSTs on forcing interannual to interdecadal variability in the winter northern hemisphere circulation. Journal of Climate 7, 1416-1441.

Grootes, P.M., Stulver, M., White, J.W.C., Johnsen, S., Jouzel, J., 1993. Comparison of oxygen isotope records from the GISP2 and GRIP Greenland ice cores. Nature $366,552-554$.

Gucu, A.C., Gucu, G., Orek, H., 2004. Habitat use and preliminary demographic evaluation of the critically endangered Mediterranean monk seal (Monachus monachus) in the Cilician Basin (Eastern Mediterranean). Biological Conservation 116 (2004), 417-431.

Guiot, J., Cheddadi, R., Prentice, I.C., Jolly, D., 1996. A method of biome and land surface mapping from pollen data: application to Europe 6000 years ago. Palaeoclimates $1,311-324$

Gutierrez Zugasti, F.I., 2006. Análisis malacológico de la Cueva de la Fragua (Santoña, Cantabria, España). In: Ferreira Bicho, N. (Ed.),Animais na Pre-História e Arqueología da Península Ibérica. Actas do IV Congresso de Arqueología Peninsular. Universidade do Algarve, Faro, pp. 197-210.

Gutiérrez Zugasti, F.I., 2009. La explotación de moluscos y otros recursos litorales en la región cantábrica durante el Pleistoceno final y el Holoceno inicial. Servicio de Publicaciones de la Universidad de Cantabria, Santander.

Harrison, S.P., Jolly, D., Laarif, F., Abe-Ouchi, A., Herterich, K., Hewitt, C., Joussaume, S., Kutzbach, J.E., Mitchell, J., Noblet, N.D., Valdes, P., 1998. Intercomparison of simulated global vegetation distributions in response to $6 \mathrm{kyr}$ BP orbital forcing. Journal of Climate 11, 2721-2742.

Harrison, S.P., Digerfeldt, G., 1991. European lakes as palaeohydrological and palaeoclimatic indicators. Quaternary Science Reviews 12, 233-248.

Harvey, J., 1982. U-S relationship and water masses in the Eastern North Atlantic. Deep-Sea Research 29, 1021-1033.

Hurrell, J.W., 1995. Decadal trends in the North Atlantic Oscillation: regional temperatures and precipitation. Science 269, 676-679.

Huthnance, J.M., 1984. Slope currents and 'JEBAR'. Journal of Physical Oceanography $14,795-810$

Johnson, W.M., Karamanlidis, A.A., Dendrinos, P., Fernández de Larrinoa, P., Gazo, M., González, L.M., Güçlüsoy, H., Pires, R., Schnellmann, M., 2006. Monk Seal Fact Files. Biology, Behaviour, Status and Conservation of the Mediterranean Monk Seal, Monachus monachus. The Monachus Guardian www.monachusguardian. org.

Johnson, W.M., Lavigne, D.M., 1999. Monk Seals in Antiquity. The Mediterranean Monk Seal (Monachus monachus) in Ancient History and Literature. Mededelin- gen 35. The Netherlands Commission for International Nature Protection, pp. 1101.

Jones, P.D., Briffa, K.R., Barnett, T.P., Tett, S.F.B., 1998. High resolution palaeoclimatic records for the last millennium: interpretation, integration and comparison with General Circulation Model control-run temperatures. The Holocene 8 (4), 455-471.

Joussaume, S., Taylor, K.E., 1995. Status of the Paleoclimate Modeling Intercomparison Project (PMIP). WCRP Report 92. In: Proceedings of the First International AMIP Scientific Conference, Monterey, pp. 425-430.

Joussaume, S., Taylor, K.E., Braconnot, P., Mitchell, J.F.B., Kutzbach, J.E., Harrison, S.P., Prentice, I.C., Broccoli, A.J., Abe-Ouchi, A., Bartlein, P.J., Bonfils, C., Dong, B., Guiot, J., Herterich, H., Hewitt, C.D., Jolly, D., Kim, J.W., Kislov, A., Kitoh, A., Loutre, M.F. Masson, V., McAvaney, B., McFarlane, N., Noblet, N., Peltier, de., Peterschmitt, W.R., Pollard, J.Y., Rind, D., Royer, D., Schelsinger, J.F., Syktus, M.E., Thompson, J., Valdes, S., Vettoretti, P.J., Webb, G., Wyputta, R.S.U., 1999. Monsoon changes for 6000 years ago: results of 18 simulations from the Paleoclimate Modelling Intercomparison Project (PMIP). Geophysical Research Letters 26, 859-862.

Lazure, P., Dumas, F., Vrignaud, C., 2008. Circulation on the Armorican shelf (Bay of Biscay) in autumn. Journal of Marine Systems 72, 218-237.

Locarnini, R.A., Mishonov, A.V., Antonov, J.I., Boyer, T.P., Garcia, H.E., 2006. World ocean atlas 2005, volume 1. Temperature. In: Levitus, S. (Ed.), NOAA Atlas NESDIS 61. U.S. Government Printing Office.

Marchal, O., Cacho, I., Stocker, T. Grimalt, J.O., Calvo, E., Martrat, B., Shackleton, N., Vautravers, M., Cortijo, E., van Kreveld, S., Andersson, C., Koc, N., Chapman, M. Sbaffi, L., Duplessy, J.-C., Sarnthein, M., Turon, J.-L., Duprat, J., Jasen, E., 2002. Apparent long-term cooling of the sea surface in the northeast Atlantic and Mediterranean during the Holocene. Quaternary Science Reviews 21, 455-483.

Marchessaux, D., Muller, N., 1987. Le Phoque Moine. Monachus monachus: distribution, statut et biologie sur la cote saharienne. Scientific Reports of the Port Cros National Park 13, 25-84.

Marín, A.B., 2004. Análisis Arqueozoológico, Tafonómico y de distribución espacial de la fauna de mamíferos de la Cueva de La Fragua (Santoña - Cantabria). Ediciones TGD.

Marín, A.B., 2008. Patrones de movilidad y control del territorio en el Cantábrico Oriental durante el Tardiglacial. Trabajos de Prehistoria 65 (1), 29-45.

Marín, A.B., 2009. The human use of the montane zone of Cantabrian Spain during the Late Glacial: faunal evidence from El Mirón Cave. Journal of Anthropological Research 65 (1), 69-102.

Marín, A.B., González-Morales, M.R., 2007. La Fragua Cave, a seasonal hunting camp in Lower Asón Valley (Cantabria, Spain) at the Pleistocene-Holocene transition. Antropozoologica 42 (1), 61-84

Mary, G., 1975. Oscillation d'age atlantique du niveau marin sur la plage de La Jerra (San Vicente de la Barquera, Santander). Breviora Geologica Asturica 19 (4), 4951.

Mary, G., Medus, J., Delibrias, G., 1975. Le Cuaternaire de la côte asturienne (Espagne). Bulletin de l'Association francaise pour l'Etude du Quaternaire 42, 13-23.

Mary, G., Medus, J., Delibrias, G., 1977. Documents sur l'évolution de la flore du Littoral Nord Espagnol au Würm. Recherches Françaisses sur le Quaternaire. INQUA 1977. Supplément au Bulletin de l'Association française pour l'Etude du Quaternaire 1 (50), 23-31.

Masson, V., Cheddadi, R., Braconnot, P., Joussaume, S., Texier, D., PMIP participants, 1999. Mid-Holocene climate in Europe: what can we infer from PMIP modeldata comparisons? Climate Dynamics 15, 163-182.

Myers, P.G., Rohling, E.J., 2000. Modeling a 200-yr interruption of the Holocene Sapropel S-1. Quaternary Research 53 (1), 98-104.

Neshyba, S.J., Mooers, C.N.K., Smith, R.L., Barber, R.T., 1989. Poleward Flows Along Eastern Ocean Boundaries. Springer-Verlag Coastal and Estuarine Studies, vol. 34. Springer-Verlag.

NOAA, 2009. Paleoclimatic Model Output Visualization. WDC for Climatology. , In: http://www.ncdc.noaa.gov/paleo/modelvis.html.

Ohgaito, R., Abe-Ouchi, A., 2009. The effect of sea surface temperature bias on the PMIP2 AOGCMs on mid-Holocene Asian monsoon enhancement. Climate Dynamics 33 (7-8), 975-983.

Peliz, A., Dubert, J., Haidvogel, D.B., Le Cann, B., 2003. Generation and unstable evolution of a Density-Driven Eastern Poleward current: the Iberian Poleward current. Journal of Geophysical Research 108, 2410-2419.

Peliz, A., Dubert, J., Santos, A.M.P., Le Cann, B., 2005. Winter upper ocean circulation in the Western Iberia Basin. Fronts, Eddies and Poleward flows: an overview. Deep-Sea Research I 52, 621-646.

Pena, L.D., Francés, G., Diz, P., Nombela, M.A., Alejo, I., 2007. Climate fluctuations during the Holocene in NW Iberia: high and low latitude linkages. Climate of the Past Discussions 3, 1283-1309.

Pérez, F.F., Mouriño, C., Fraga, F., Ríos, A.F., 1993. Displacement of water masses and remineralization rates off the Iberian Peninsula by nutrient anomalies. Journal of Marine Research 51, 869-892.

Pérez, F.F., Pollard, R.T., Read, J.F., Valencia, V., Cabanas, J.M., Ríos, A.F., 2000. Climatological coupling of the thermohaline decadal changes in central water of the eastern North Atlantic. Scientia Marina 64 (3), 347-353.

Pérez Ripoll, M., Raga, J.A., 1998. Los mamíferos marinos en la vida y en el arte de la prehistoria de la Cueva de Nerja. In: Sanchidrian, J.L., Simón, M.D. (Eds.), Las culturas del Pleistoceno Superior en Andalucia. Patronato de la Cueva de Nerja, Malaga, pp. 251-275.

Pingree, R.P., New, A.L., 1989. Downward propagation of internal tidal energy into the Bay of Biscay. Deep-Sea Research 36, 735-758. 
Pollard, R.T., Griffiths, M.J., Cunningham, S.A., Read, F.F., Pérez, F.F., Ríos, A.F., 1996. Vivaldi 1991. A study of the formation, circulation and ventilation of Eastern North Atlantic Central Water. Progress in Oceanography 37, 167-192.

Postel, E., 1950. Un phoque tropical: le phoque moine. La Nature 3187 (Novembre 1950), 341-342.

Prentice, I.C., Guiot, J., Huntley, B., Jolly, D., Cheddadi, R., 1996. Reconstructing biomes from palaeoecological data: a general method and its application to European pollen data at 0 and $6 \mathrm{ka}$. Journal of Climate 12, 185-194.

Ríos, A.F., Pérez, F.F., Fraga, F., 1992. Water masses in the upper and middle North Atlantic Ocean east of the Azores. Deep-Sea Research 39, 645-658.

Roca, J.R., Julia, R., 1997. Late-Glacial and Holocene lacustrine evolution based on Ostracode assemblages in Southeastern Spain. Geobios 30 (6), 823-830.

Rohling, E.J., De Rijk, S., 1999. Holocene climate optimum and Last Glacial Maximum in the Mediterranean: the marine oxygen isotope record. Marine Geology 153, 57-75.

Rossby, T., 1996. The North Atlantic current and surrounding waters: at the crossroads. Review of Geophysics 34, 463-481.

Rowell, D.P., Rodwell, M.J., 1999. Oceanic forcing of the wintertime North Atlantic Oscillation and European climate. Nature 398, 320-323.

Ruddiman, W.F., 1992. Fossil Plankton Stratigraphies. IGBP PAGES/World Data Center-A for Paleoclimatology Data Contribution Series \# 92-005. NOAA/NGDC Paleoclimatology Program, Boulder, CO, USA.

Ruddiman, W.F. Mix, A.C., 1993. The north and equatorial Atlantic at 9000 and 6000 yr BP. In: Wright, Jr., H.E., Kutzbach, J.E., Webb, III, T., Ruddiman, W.F., StreetPerrott, F.A., Bartlein, P.J. (Eds.), Global Climates since the Last Glacial Maximum. University of Minnesota Press, Minneapolis, pp. 149-220.

Ruff, C.B., 2005. Climatic adaptation and hominid evolution: the thermoregulatory imperative. Evolutionary Anthropology 2 (2), 53-60.

Schmölcke, U., 2008. Holocene environmental changes and the seal (Phocidae) fauna of the Baltic Sea: coming, going and staying. Mammal Review 38 (4), $231-$ 246.

Serangeli i Dalmau, J., 2001. La zona de costa en Europa durante la última glaciación. Consideraciones al análisis de restos y representaciones de focas, cetáceos y alcas gigantes. Cypsela 13, 123-138.

Sommer, R., Benecke, N., 2003. Post-Glacial history of the European seal fauna on the basis of sub-fossil records. Beiträge Zu Archäozoologie und Prähistorischer Anthropologie 6, 16-28.

Steig, E.J., 1999. Mid-Holocene climate-change. Science 286 (5444), 1485-1487.

Straus, L.G., 1992. Iberian before the Iberians. In: The Stone Age Prehistory of Cantabrian Spain, University of New Mexico Press, Alburquerque.
Straus, L.G., 2005. The Upper Paleolithic of Cantabrian Spain. Evolutionary Anthropology 14, 145-158.

Stringer, C.B., Finlayson, J.C., Barton, R.N.E., Fernández-Jalvo, Y., Cáceres, I., Sabin, R.C., Rhodesi, E.J., Currant, A.P., Rodríguez-Vidal, J., Giles-Pacheco, F., RiquelmeCantal, J.A., 2008. Neanderthal exploitation of marine mammals in Gibraltar. PNAS 105 (38), 14319-14324.

Sutton, R.T., Hodson, D.L.R., 2005. Atlantic Ocean forcing of North American and European summer climate. Science 309 (5731), 115-118.

Terral, J.F., Mengual, X., 1999. Reconstruction of Holocene climate in southern France and eastern Spain using quantitative anatomy of olive woodland archaeological charcoal. Palaeogeography, Palaeoclimatology, Palaeoecology 153 71-92.

Trauth, M.H., Maslin, M.A., Deino, A.L., Strecker, M.R., Bergner, A.G.N., Dühnforth, M., 2007. High- and low-latitude forcing of Plio-Pleistocene East African climate and human evolution. Journal of Human Evolution 53 (5), 475-486.

UNEP//MAP, 1994. Present status and trend of the Mediterranean monk seal (Monachus monachus) populations. Ref: Anex 15. UNEP//MAP.In: Meeting of Experts on the Evaluation of the Implementation of the Action Plan for the Management of the Mediterranean Monk Seal. Morocco, 7-9, October 1994 RAC//SPA (UNEP), Tunis, UNEP (OCA)/MED WG. 87/3.

Vega del Sella, Conde de la, 1916. Paleolítico de Cueto de la Mina (Asturias). Comisión de Investigaciones Paleontológicas y Prehistóricas, 13.

Vega del Sella, Conde de la, 1921. Notas para la Climatología Cuaternaria del Cantábrico. C. I. P. P., 38.

Vega del Sella, Conde de la., 1923. El Asturiense. Nueva industria preneolítica. Comisión de Investigaciones Paleontológicas y Prehistóricas, 32 (Serie Prehistórica 27).

Visbeck, M., 2002. The ocean's role in Atlantic climate variability. Science 297 (5590), 2223-2224.

von Grafenstein, U., Erlenkeuser, H., Brauer, A., Jouzel, J., Johnsen, S.J., 1999. A midEuropean decadal isotope-climate record from 15,500 to 5000 years B.P. Science 284 (5420), 1654-1657.

Weber, S.L., 2001. The impact of orbital forcing on the climate of an intermediatecomplexity coupled model. Global and Planetary Change 30, 7-12.

Wyss, A., 1988. On "retrogression" in the evolution of the Phocinae and Phylogenetic affinities of the monk seals. American Museum Novitates 2924, 1

Zhao, M., Beveridge, N.A.S., Shackleton, N.J., Sarnthein, M., Eglinton, G., 1995. Molecular stratigraphy of cores off northwest Africa: sea surface temperature history over the last $80 \mathrm{ka}$. Paleoceanography 10 (3), 661-675. 